\title{
Pendidikan Kesehatan Deteksi Dini Kanker Payudara sebagai Upaya Promosi Kesehatan Wanita Pasangan Usia Subur
}

\author{
Witdiawati, Laily Rahayuwati, Dadang Purnama \\ Fakultas Keperawatan, Universitas Padjadjaran \\ Email : witdiawati14001@unpad.ac.id
}

\begin{abstract}
Abstrak
Kanker payudara merupakan salah satu penyakit yang masih menjadi ancaman bagi wanita di seluruh dunia. Diketahui bahwa pada tahun 2012 terdapat 14.067.894 kasus baru kanker dan 8.201.575 kematian akibat kanker payudara. Deteksi dini merupakan salah satu upaya untuk mencegah dan menanggulangi kanker payudara sejak dini. Tujuan kegiatan ini adalah untuk memberikan pendidikan kesehatan tentang deteksi dini kanker payudara dengan tehnik SADARI pada wanita usia subur sehingga dapat menjadi upaya promosi kesehatan dalam pencegahan kanker payudara. Metoda pelaksanaan Program Pengabdian Masyarakat ini adalah pendidikan masyarakat dalam bentuk penyuluhan kesehatan, di evaluasi dengan pre test dan post test dengan analisis kuantitatif. Jumlah peserta wus yang hadir 26 orang, 12 orang mahasiswa, dan 2 orang kader kesehatan. Kegiatan dimulai dari tahapan perencanaan, pelaksanaan, evaluasi, hingga penyusunan laporan. Hasil kegiatan ada perubahan dalam pengetahuan dengan rata-rata pre test $88,5 \%$ pengetahuan peserta berada di kategori kurang dan hasil post test $92,3 \%$ berada dikategori baik. Dalam aspek keterampilan, seluruh peserta wus yang hadir (100\%) dapat mempraktekan kembali tehnik SADARI. Kesimpulan. Kegiatan pendidikan kesehatan tentang deteksi dini kanker payudara dapat menjadi salah satu upaya untuk meningkatkan pengetahuan dan promosi kesehatan WUS dalam pencegahan dan pengendalian kanker payudara melalui deteksi dini dengan tehnik SADARI. Diharapkan kegiatan ini dapat menjadi strategi promosi kesehatan wus dalam pencegahan dan pengendalian kanker payudara. Perlu adanya sosialisasi lanjutan dan evaluasi berkala dari petugas kesehatan dalam beberapa program kesehatan berbasis masyarakat sehingga seluruh pelayanan kesehatan dapat tersosialisasikan dengan baik.
\end{abstract}

Kata kunci : Deteksi dini, kanker payudara, pendidikan kesehatan, promosi kesehatan.

\begin{abstract}
Breast cancer is the most common cancer for women in the world. It is estimated that 14.067.894 women were diagnosed with breast cancer worldwide in 2012 and 8.201 .575 the mortality cancer cases in woman. The purpose of this activity is to provide health education to women for a health promotion effort in the prevention of breast cancer. Implementation method is community education in the form of health counseling with a total of 26 participants, 12 students, and 2 health cadres. Stage of activity star from planning, implementation, evaluation, to the preparation of reports. Results. The results of the activity have significant changes in knowledge with an average pre test of $88.5 \%$ of participants' knowledge in the less category and the post test results of $92.3 \%$ in the good category. In the skill aspect, all participants who were presented (100\%) were able to practice the BSE technique again. Conclusion. The activity received appreciation from all women of childbearing age and health cadres who attended. It is hoped that this activity can become a strategy for promoting health in preventing and controlling breast cancer. There needs to be continued socialization and periodic evaluation of health workers in several community-based health programs so that all health services can be well socialized.
\end{abstract}

Keywords : early detections, breast cancer, health education, health promotion 


\section{Pendahuluan}

Kanker payudara menjadi salah satu kanker yang paling menakutkan bagi perempuan di dunia dan juga di Indonesia. Berdasarkan data GLOBOCAN, International Agency for Research on Cancer (IARC), diketahui bahwa pada tahun 2012 terdapat 14.067.894 kasus baru kanker dan 8.201.575 kematian akibat kanker diseluruh dunia. Penyakit kanker serviks dan payudara merupakan penyakit kanker dengan prevalensi tertinggi di Indonesia pada tahun 2013, yaitu kanker serviks sebesar 0,8\%o dan kanker payudara sebesar 0,5 (Depkes, 2016). Pengendalian dan pencegahan dengan deteksi dini menjadi salah satu upaya untuk menurunkan anacaman kanker payudara.

Garut merupakan salah satu dari kabupaten yang secara geografis terletak di sebelah selatan provinsi jawa barat. Cakupan deteksi dini kanker payudara dengan pemeriksaan klinia CBE (Clinical Breast Examination) di kabupaten Garut pada tahun 2016, jumlah perempuan dengan kategori usia 30-50 tahun mencapai 2.55 .173 orang namun hanya 2.090 (1\%) yang melakukan skrining atau deteksi dini, dengan hasil deteksi 40 orang (1,38\%) mempunyai tumor atau benjolan dipayudara (Dinkes Kab Garut, 2017). Hasil wawancara dengan 6 wanita usia subur (WUS) di wilayah kerja Puskesmas Haurpanggung 5 orang diantaranya mengatakan bahwa belum mengetahui cara deteksi dini kanker payudara, baik dengan tehnik SADARI atau pun Mammografi.

WHO (1986), mendefinikan promosi kesehatan sebagai proses yang memungkinkan orang untuk meningkatkan kontrol atas dan untuk meningkatkan kesehatan mereka. Ini merupakan pendekatan komprehensif untuk membawa perubahan sosial dalam meningkatkan kesehatan dan kesejahteraan. Fokus penekanan pada perilaku kesehatan yang secara signifikan yang tercermin oleh lima elemen Piagam Ottawa diantaranya membangun kebijakan publik yang sehat, mengorientasi kembali layanan kesehatan, menciptakan lingkungan yang mendukung, memperkuat aksi masyarakat, dan mengembangkan keterampilan individu (HSE, 2011). Tujuan akhir yang diharapkan dari suatu promosi atau pendidikan kesehatan adalah perubahan perilaku kesehatan, atau perilaku untuk memelihara dan meningkatkan kesehatan oleh sasaran dari promosi kesehatan. Pendidikan kesehatan secara umum didefinisikan sebagai upaya yang direncanakan untuk mempengaruhi orang lain, baik individu, kelompok, atau masyarakat, sehingga mereka dapat melakukan apa yang diharapkan oleh pelaku pendidikan atau promotor kesehatan (Notoadmojo, 2012).

Ada beberapa faktor pemicu munculnya kanker payudara salah satunya adalah faktor genetik, lingkungan dan gaya hidup (Dekpes, 2016). Tingkat pengetahuan tentang kanker payudara pun masih sangat rendah, sehingga kesadaran deteksi dini menjadi hal yang sangat 
penting dalam pengendalian kanker payudara. Ketika kanker payudara dapat dideteksi secara dini dan didiagnosis serta mendapat pengobatan yang memadai, maka ada peluang untuk dapat disembuhkan (Depkes, 2016). Kurang terpaparnya masyarakat tentang deteksi dini kanker payudara di tengarai dapat menjadi salah satu penyebab rendahnya kesadaran masyarakat untuk melakukan deteksi dini kanker payudara. Sehingga perlu adanya satu upaya edukasi kepada masyarakat untuk dapat mensosialisasikan pencegahan dan penanggulangan kanker payudara. Edukasi berbasis masyarakat bukan hanya memberikan penyuluhan akan tetapi ada keterlibatan dari masyarakat. Keterlibatan masyarakat dalam deteksi dini dapat dilakukan melalui kader kesehatan dan masyarakat (Sari, C. W. M., \& Yamin, A, 2018).

Desa Jayaraga merupakan salah satu desa yang berada diwilayah kerja Puskesmas Haurpanggung dan menjadi salah satu desa yang dijadikan lokasi Kegiatan Pengabdian Masyarakat yang terintegrasi dengan mata kuliah Pendidikan dan Promosi Kesehatan. Berdasarkan data puskesmas, dalam 2 tahun terakhir ditemukan 2 kasus kematian akibat kanker payudara. Salah satunya berada di desa Jayaraga. Kegiatan PPM ini di inisiasi dari rencana tindak lanjut kegiatan peningkatan kapasitas kader desa Jayaraga tentang deteksi dini kanker payudara pada tahun 2017. Tujuan kegiatan PPM ini adalah memberikan pendidikan kesehatan pada wanita usia subur melalui peningkatan pengetahuan dan keterampilan masyarakat, terutama WUS dalam melakukan deteksi dini kanker payudara dengan tehnik Sadari sehingga dapat menjadi upaya promosi kesehatan dalam pencegahan kanker payudara dan dapat menjadi motivasi meningkatnya kesadaran WUS dalam melakukan deteksi dini kanker payudara serta meningkatkan partisipasi aktif dari masyarakat dalam upaya sosialisasi deteksi dini kanker payudara. Edukasi tepat sasaran merupakan strategi yang dapat dilakukan dalam pendidikan kesehatan ini. Sehingga sasaran dalam kegiatan PPM ini adalah wanita pasangan usia subur.

Berdasarkan uraian diatas, maka kami selaku tim mengambil tema kegiatan PPM ini adalah "Pendidikan Kesehatan Deteksi Dini Kanker Payudara Sebagai Upaya Promosi Kesehatan Wanita Pasangan Usia Subur" Di RW 12 Desa Jayaraga Wilayah Kerja Puskesmas Haurpanggung, Kabupaten Garut”.

\section{Metode}

Metode pelaksanaan Program Pengabdian Masyarakat ini adalah pendidikan masyarakat dalam bentuk penyuluhan kesehatan. Pendidikan kesehatan dalam bentuk penyuluhan kesehatan menjadi inspirasi dari kegiatan PPM (Program Pengabdian Masyarakat), karena berdasarkan hasil studi pendahuluan wawancara dengan beberapa WUS di RW 12 desa 
Jayaraga, sebagian besar WUS mengatakan belum terpapar informasi tentang deteksi dini kanker payudara. Jumlah peserta WUS yang hadir dalam pelaksanaan kegiatan adalah 26 orang dan 3 orang kader. Selain kader kesehatan, 12 orang mahasiswa, 1 orang aparat desa turut hadir dalam pelaksanaan kegiatan. Kegiatan pendidikan kesehatan di laksanakan pada hari minggu, 19 Mei 2019 pukul 08.00 s/d 11.00 WIB bertempat di Aula RT 02 RW 12 Desa Jayaraga.

Kegiatan dimulai dari tahapan perencanaan/ persiapan yang diawali dengan berkoordinasi dengan pengurus kader RW 12 untuk menyepakati kembali tujuan, waktu dan tempat dan peserta dari pelaksanaan kegiatan. Pelaksanaan kegiatan pendidikan kesehatan terdiri dari tiga kegiatan utama yaitu sesi pertama brainstorming kemudian dilanjut sesi kedua yaitu penyuluhan tentang kanker payudara dengan konten materi pengertian kanker payudara, penyebab kanker payudara, tanda dan gejala kanker payudara serta cara deteksi dini kanker payudara. Kegiatan penyuluhan diawali dengan pre test kemudian dilanjutkan dengan pemberian materi serta pemutaran video terkait kanker payudara dan simulasi atau praktik secara langsung tehnik SADARI (Periksa payudara sendiri) sebagai salah satu tehnik untuk deteksi dini kanker payudara. Sesi ketiga merupakan sesi diskusi tanya jawab dan diakhiri dengan post test sebagai evaluasi kegiatan penyuluhan. Kegiatan dipandu oleh narasumber sebagai fasilitator dengan dibantu peralatan dan perlengkapan pendukung pelatihan seperti leaflet, video, pantoom dan media visual/LCD. Untuk mengevaluasi signifikansi kegiatan pelatihan terhadap pengetahuan WUS dilakukan analisis kuantitatif distribusi frekuensi. Sedangkan untuk mengevaluasi keterampilan peserta WUS dalam melakukan tehnik SADARI, di evaluasi dengan melihat kemampuan WUS secara langsung dalam mensimulasikan tehnik SADARI.

\section{Hasil}

Pelaksanaan kegiatan Pengabdian mendapat apresiasi penuh dari peserta yang hadir. Peserta tampak antusias mengikuti kegiatan dari awal sampai akhir sesi penyuluhan. Antusias peserta tampak terutama saat sesi diskusi dan tanya jawab. Pada saat simulasi praktek SADARI, ditemukan satu peserta WUS yang merasakan ada benjolan di payudaranya sehingga di sarankan untuk di lakukan pemeriksaan lebih lanjut. Adapun karakteristik peserta WUS yang hadir dalam kegiatan pendidikan dan promosi kesehatan adalah sebagai berikut: 
Tabel 1.Karakateristik WUS dalam Pendidikan dan promosi kesehatan deteksi dini kanker payudara di RW 12 Desa Jayaraga Wilayah Binaan Puskesmas Haurpanggung $(\mathbf{N}=\mathbf{2 6})$

\begin{tabular}{|c|c|c|c|}
\hline No. & Variabel & $\mathbf{N}$ & Persentase (\%) \\
\hline \multirow[t]{4}{*}{1.} & Usia: & & \\
\hline & $30-40$ tahun & 10 & 38,5 \\
\hline & $41-50$ tahun & 12 & 46,1 \\
\hline & $51-60$ & 4 & 15,4 \\
\hline \multirow[t]{2}{*}{2.} & Status: & & \\
\hline & Menikah & 26 & 100 \\
\hline \multirow[t]{2}{*}{3.} & Suku : & & \\
\hline & Sunda & 26 & 100 \\
\hline \multirow[t]{4}{*}{4.} & Pekerjaan : & & \\
\hline & Tidak bekerja/IRT & 20 & 78 \\
\hline & Buruh & 3 & 11,5 \\
\hline & Wiraswasta & 3 & 11,5 \\
\hline \multirow[t]{4}{*}{5.} & Pendidikan: & & \\
\hline & SD & 4 & 15,4 \\
\hline & SLTP & 14 & 54 \\
\hline & SLTA & 8 & 30,8 \\
\hline \multirow[t]{3}{*}{6.} & Kepemilikan Asuransi: & & \\
\hline & $\mathrm{Ya}$ & 16 & 61,5 \\
\hline & Tidak & 10 & 38,5 \\
\hline \multirow[t]{3}{*}{7.} & $\begin{array}{l}\text { Pernah mendapat edukasi } \\
\text { tentang Kanker payudara }\end{array}$ & & \\
\hline & $\mathrm{Ya}$ & 3 & 11,5 \\
\hline & Tidak & 23 & 88,5 \\
\hline \multirow[t]{4}{*}{8.} & Riwayat keluarga & & \\
\hline & Kanker/tumor payudara & & \\
\hline & $\mathrm{Ya}$ & 1 & 3,8 \\
\hline & Tidak & 25 & 96,2 \\
\hline
\end{tabular}

Dari tabel 1, usia wus yang mengikuti penyuluhan sebagian besar lebih berusia 41-50 tahun (46,1\%). Hampir seluruh wus adalah ibu rumah tangga (78\%). Tingkat pendidikan wus, hampir sebagian besar adalah SLTP (54\%). Hampir seluruh WUS belum pernah mendapatkan edukasi tentang deteksi dini Kanker Payudara (88.5\%). Sebagian besar wus mempunyai asuransi kesehatan bpjs (61\%) dan 1 orang WUS (3,8\%) mempunyai riwayat keluarga dengan kanker/tumor payudara.

Uji distribusi pengetahuan WUS dilakukan sebelum dan sesudah pelatihan. Hasil untuk pengetahuan sebelum adalah 88,5 \% dalam kategori kurang sedangkan untuk pengetahuan sesudah adalah 92,3\% dalam kategori baik. 
Tabel 2. Distibusi Pengetahuan WUS tentang deteksi dini kanker payudara Sebelum dan Sesudah Pendidikan kesehatan $(\mathrm{N}=26)$

\begin{tabular}{lllcccccc}
\hline No & Test & \multicolumn{3}{c}{ Baik } & \multicolumn{3}{c}{ Cukup } & \multicolumn{3}{c|}{ Kurang } \\
& & $\mathrm{f}$ & $\%$ & $\mathrm{f}$ & $\%$ & $\mathrm{f}$ & $\%$ \\
\hline 1 & Pre test & 2 & 7,7 & 1 & 3,8 & 23 & 88,5 \\
2 & Post test & 24 & 92,3 & 2 & 7,7 & 0 & 0 \\
\hline
\end{tabular}

Berdasarkan tabel 2, dilihat dari dari distribusi jawaban peserta pada saat pre test dan hasil post test ada peningkatan pengetahuan WUS tentang kanker payudara dan deteksi dini. Selain pengetahuan, dalam aspek keterampilan deteksi dini dengan tehnik SADARI, seluruh peserta WUS (100\%) dapat mempraktekan kembali tehnik SADARI dengan benar. Saat diskusi tanya jawab, disimpulkan ada keinginan dan antusias dari peserta WUS untuk mengetahui lebih dalam tentang kanker payudara dan penatalaksanaan pengobatan, perawatan dan penegakan diagnosis, tidak hanya sebatas deteksi dini saja.

\section{Pembahasan}

Berdasarkan hasil evaluasi kegiatan, pendidikan kesehatan dengan bentuk penyuluhan dan simulasi langsung dapat menjadi salah satu upaya untuk meningkatkan pengetahuan WUS tentang deteksi dini kanker payudara. Setelah di beri pendidikan kesehatan terjadi input kognitif pada peserta lalu perubahan konseptual dan setelah itu itu terdapat output, sehingga peserta dapat memahami pembelajaran dan peserta dapat menjawab soal postest dengan baik. Hal ini sejalan dengan cognitivism theory, dimana teori ini menjelaskan bahwa pengetahuan seseorang merupakan akibat dari adanya input lalu terjadi perubahan konseptual setelah itu terdapat output atau hasil dari perubahan konseptual tersebut yang disampaikan melalui sebuah pembelajaran (Glanz,et.al, 2008).

Selain metode, media penyuluhan dalam bentuk video juga menjadi salah satu daya tarik sehingga peserta lebih antusias saat mengikuti materi penyuluhan. Antusias WUS pada kegiatan PPM ini terlihat pada saat sesi diskusi. Banyak pertanyaan yang di lontarkan peserta baik WUS maupun kader terkait perawatan dan pengobatan kanker payudara. Media audio visual khususnya mempunyai fungsi menarik dan mengarahkan perhatian sasaran untuk konsentrasi terhadap materi yang ditampilkan (fungsi atensi), dapat menggugah emosi dan sikap sasaran (fungsi afektif), dapat mempermudah sasaran dalam memahami dan mengingat pesan yang terkandung dalam materi (fungsi kognitif), dan membantu sasaran yang lemah dan lambat dalam menerima dan memahami materi yang disampaikan secara teks maupun 
verbal (fungsi kompensatoris) (Arsyad, 1996 ; Aeni, N., \& Yuhandini, D. S, 2018). Senada dengan peneitian tersebut, Kapti, Rustina \& Widyatuti (2013), dalam hasil penelitian quasy eksperimennya menyimpulkan bahwa audiovisual efektif sebagai media penyuluhan terhadap perubahan pengetahuan dan sikap ibu. Ada peningkatan pengetahuan dan sikap setelah penyuluhan antara kontrol dan intervensi terdapat perbedaan yang bermakna (pengetahuan: $p=0,01 ; \alpha=0.05$; sikap: $p=0,036 ; \alpha=0.05)$.

Tingkat pendidikan WUS juga menjadi salah satu faktor dalam perilaku SADARI (Kurniawati, D., 2015). Kegiatan pendidikan kesehatan ini dapat menjadi salah satu komponen yang menjadi dasar perilaku WUS dalam melakukan deteksi dini kanker payudara secara berkala, terutama dengan tehnik SADARI. Pendidikan kesehatan mempunyai hubungan yang signifikan dengan sikap dan pengetahuan WUS dalam perilaku SADARI (Angrainy, R.,2017; Diniar, O. R., Maliya, A., \& Ambarwati, S. P. , 2013; Ekanita, P., \& Khosidah, A., 2013; Handayani, D. S. (2008). Integrasi pendidikan kesehatan dan promosi kesehatan memegang peran penting dalam program pengendalian penyakit kronik karena dianggap hemat biaya (Xu, Q., Chen, B., Jin, D., Li, Y., \& Huang, Y., 2019). Strategi penyuluhan langsung ke sasaran dapat menjadi lebih efektif dalam proses transfer informasi. Memberikan edukasi atau pendidikan kesehatan secara langsung kepada WUS dapat meningkatkan antusias WUS untuk mengenal lebih jauh tentang kanker payudara dan deteksi dini. Selain perilaku deteksi dini, keterlibatan masyarakat (WUS) dalam mengenal kanker payudara dapat meningkatkan dukungan masyarakat terhadap penderita kanker payudara. Kurang terpaparnya masyarakat tentang kanker payudara diprediksi menjadi salah penyebab kurangnya dukungan sosial masyarakat terhadap klien dengan kanker Payudara. Dimana dukungan tersebut akan muncul seiring dengan meningkatnya pengetahuan masyarakat terhadap masalah kanker payudara (Witdiawati, Sukmawati \& Mamuroh, 2018).

\section{Simpulan}

Kegiatan PPM mendapat aspirasi dari masyarakat terutama WUS yang hadir dalam kegiatan. Pendidikan kesehatan dapat menjadi salah satu upaya untuk promosi kesehatan tentang deteksi dini kanker payudara pada WUS. Perlu adanya sosialisasi lanjutan dan evaluasi berkala dari petugas kesehatan dalam beberapa program kesehatan berbasis masyarakat sehingga seluruh pelayanan kesehatan dapat tersosialisasikan dengan baik. Kader kesehatan merupakan salah satu komponen masyarakat yang dapat dioptimalkan perannya dalam sosialisasi pencegahan dan pengendalian kanker payudara. 


\section{Ucapan Terimakasih}

Penulis menyampaikan terimakasih kepada semua pihak yang telah membantu dalam pelaksanaan kegiatan Program Pengabdian Masyarakat ini. Secara khusus penulis ingin mengucapkan terimakasih dan penghargaan yang setinggi-tingginya kepada: Prof. Dr. Med. Tri Hanggono Achmad, dr., selaku Rektor Universitas Padjadjaran dan Hj. Henny Suzana Mediani.S.Kp.,MNg.,Ph.D, selaku Dekan Fakultas Keperawatan Universitas Padjadjaran atas kesempatan dan dukungan yang telah diberikan kepada penulis untuk dapat melaksanakan kegiatan Program Pengabdian Masyarakat ini. Penulis juga menyampaikan terimakasih kepada Kepala desa Jayaraga Kabupaten Garut, Puskesmas Haurpanggung Kabupaten Garut, serta para kader kesehatan RW 12 Desa Jayaraga, atas kesempatan dan partisipasinya dalam pelaksanaan kegiatan Program Pengabdian Masyarakat ini. Dan juga kepada mahasiswa angkatan 2016 Fakultas Keperawatan Kampus Garut (Kelompok Pendidikan dan Promosi Kesehatan Tehnik Sadari) atas integrasi dan partisipasinya dalam kegiatan PPM. Semoga Alloh SWT membalasnya.

\section{Daftar Pustaka}

Aeni, N., \& Yuhandini, D. S. (2018). Pengaruh Pendidikan Kesehatan Dengan Media Video Dan Metode Demonstrasi Terhadap Pengetahuan SADARI. Care: Jurnal Ilmiah Ilmu Kesehatan, 6(2), 162-174.

Angrainy, R. (2017). Hubungan pengetahuan, sikap tentang SADARI dalam mendeteksi dini kanker Payudara pada remaja. Jurnal Endurance: Kajian Ilmiah Problema Kesehatan, 2(2), 232-238.

Depkes RI (2016). Infodatin. Pusat data dan Informasi Kanker payudara. http://www.depkes.go.id/resources/download/pusdatin/infodatin/infodatin-kanker.pdf.

Dinas Kesehatan kabupaten Garut (2017). Profil Kesehatan Kabupaten Garut 2017.

Diniar, O. R., Maliya, A., \& Ambarwati, S. P. (2013). Pengaruh Pendidikan Kesehatan Tentang Pencegahan Kanker Payudara Terhadap Tingkat Pengetahuan Dan Sikap Pada Wanita Usia Produktif Di Desa Sumur Musuk Boyolali (Doctoral dissertation, Universitas Muhammadiyah Surakarta).

Ekanita, P., \& Khosidah, A. (2013). Hubungan antara pengetahuan dan sikap WUS terhadap perilaku pemeriksaan payudara sendiri (SADARI). Bidan Prada: Jurnal Publikasi Kebidanan Akbid YLPP Purwokerto, 4(02).

Glanz, K., Rimer, B. K., \& Viswanath, K. (Eds.). (2008). Health behavior and health education: theory, research, and practice. John Wiley \& Sons. 
Handayani, D. S. (2008). Hubungan antara tingkat pengetahuan dan sikap dengan perilaku para wanita dewasa awal dalam melakukan pemeriksaan payudara sendiri di kelurahan kalangan kecamatan pedan klaten (Doctoral dissertation, Universitas Diponegoro).

Kapti, R. E., Rustina, Y., \& Widyatuti, W. (2013). Efektifitas audiovisual sebagai media penyuluhan kesehatan terhadap peningkatan pengetahuan dan sikap ibu dalam tatalaksana balita dengan diare di dua rumah sakit kota Malang. Jurnal Ilmu Keperawatan, 1(1), 53-60.

Kurniawati, D. (2015). Hubungan Pendidikan, Pengetahuan dan Sikap Wanita Usia Subur (WUS) dengan Pemeriksaan Payudara Sendiri (SADARI) Di Wilayah Kerja Puskesmas Dara Juanti Kabupaten Sintang Tahun 2014. Jurnal Ilmiah Ilmu Kesehatan: Wawasan Kesehatan, 1(2), 15-27.

Sari, C. W. M., \& Yamin, A. (2018). Edukasi Berbasis Masyarakat untuk Deteksi Dini Diabetes Melitus Tipe 2. Media Karya Kesehatan, 1(1).

Witdiawati, W., Sukmawati, S., \& Mamuroh, L. (2018). Penguatan Kapasitas Kader Kesehatan dalam Upaya Meningkatkan Dukungan Sosial Berbasis Masyarakat terhadap Klien Kanker Payudara. Media Karya Kesehatan, 1(1).

Xu, Q., Chen, B., Jin, D., Li, Y., \& Huang, Y. (2019). An assessment for health education and health promotion in chronic disease demonstration districts: A comparative study from hunan province, china. PeerJ, doi:http://dx.doi.org/10.7717/peerj.657. 